\title{
PENINGKATAN PEMBELIAN ULANG MELALUI PROMOSI, CITRA PERUSAHAAN, PELAYANANAN DENGAN MEDIASI KEPUASAN PELANGGAN
}

\author{
R. R Eko Setyowati Redjeki, Ngatno \\ Program Studi Magister Ilmu Komunikasi Universitas Diponegoro
}

\begin{abstract}
Abstrak
Sejak diberlakukannya lelang elektronik, persaingan bisnis jasa konstruksi sangat tinggi. Hal ini berdampak pada berkurangnya paket pekerjaan dan penurunan jumlah pelanggan, sehingga mengurangi pendapatan dan laba perusahaan. Tujuan dari studi ini adalah menganalisis pengaruh promosi, citra perusahaan, pelayanan terhadap kepuasan pelanggan dalam meningkatkan pembelian ulang. Penelitian ini menggunakan pendekatan kuantitatif eksplanatori dengan metode survei. Sampel penelitian adalah sebanyak 53 user CV. Selaksa Prada, diambil dengan menggunakan metode sensus. Teknik analisis data digunakan analisis jalur. Hasil penelitian menunjukkan terdapat pengaruh positif promosi, citra perusahaan, pelayanan terhadap kepuasan pelanggan. Hasil selanjutnya menjelaskan terdapat pengaruh positif promosi, citra perusahaan, pelayanan dan kepuasan pelanggan terhadap pembelian ulang.
\end{abstract}

Kata kunci: promosi, citra perusahaan, pelayanan, kepuasan pelanggan, pembelian ulang.

\section{Abstract}

Since the introduction of electronic auctions, the competition of construction services business is very high. These results in reduced work packages and decreases in subscriber numbers, thereby reducing earnings and profits. The purposes of this study are to analyze the influence of promotion, corporate image, and service to customer satisfaction, toward increase repeat purchase. This study used explanatory quantitative approach with survey method. The samples of research are 53 users CV. Selaksa Prada, taken using the census method. Data analysis techniques path analysis. The results showed there are positive influences of promotion, corporate image, and service to customer satisfaction. The results further explain that there are positive influences of promotion, corporate image, service, and customer satisfaction with repeat purchase

Keywords : Promotion, Corporate image, service quality, Customer satisfaction, Repeat purchase 


\section{Pendahuluan}

Pembelian ulang adalah keinginan dan tindakan konsumen untuk membeli ulang suatu produk karena adanya kepuasan yang diterima sesuai yang diinginkan dari suatu produk. Mempertahankan pelanggan untuk mendapatkan pelanggan yang loyal bukanlah pekerjaan yang mudah (sulit) bagi perusahaan apalagi dalam jangka waktu yang lama.

Kesulitan mempertahankan pelanggan juga dialami oleh CV. Selaksa Prada Semarang yang bergerak di bidang pelaksanaan jasa konstruksi. Sejak diberlakukannya Peraturan Presiden RI Nomer 54 tahun 2010 tentang Pengadaan Barang dan Jasa Pemerintah, persaingan dunia usaha khususnya usaha jasa konstruksi semakin ketat. Persaingan pasar semakin ketat, banyaknya kompetitor-kompetitor bersaing mendapatkan proyek pekerjaan, mengakibatkan order proyek dan pendapatan kontraktor setempat menurun.

Munculnya kompetitor baru menyebabkan order menyempit dan otomatis pendapatan perusahaan mengalami penurunan. Jumlah pelanggan CV. Selaksa Prada dari tahun 2014 - 2016 semakin mengalami penurunan, dari 61 user menjadi 53 user. Begitupula jumlah pelanggan loyal dari 52 user di tahun 2014 menurun menjadi 48 di tahun 2016. Hal serupa terjadi pula pada User baru di tahun 2014 sebanyak 9 user mengalami penurunan menjadi 5 (Tabel 1).

Tabel 1.

Pelanggan CV Selaksa Prada Tahun 2014-2016

\begin{tabular}{|c|c|c|c|}
\hline \multirow{2}{*}{ Tahun } & \multicolumn{3}{|c|}{ Pelanggan } \\
\cline { 2 - 4 } & Loyal & Baru & Jumlah \\
\hline 2014 & 52 & 9 & 61 \\
\hline 2015 & 50 & 7 & 57 \\
\hline 2016 & 48 & 5 & 53 \\
\hline
\end{tabular}

Sumber : olah data peneliti

Terdapat beberapa faktor yang dapat mendorong pembelian ulang pelanggan, di antaranya adalah bauran pemasaran. Menurut hasil studi Cengiz dan Yayla (2007), komponen Marketing mix yang dikenal "7 Ps", terdiri price (harga), product (produk), promotion (promosi) place (saluran distribusi), serta ditambah people (personal), physical evidence (bukti fisik), dan process (proses) memiliki pengaruh terhadap kepuasan dan loyalitas pelanggan, menuju word of mouth (komunikasi dari mulut ke mulut). Penelitian ini memfokuskan pada komponen bauran pemasaran promotion (promosi), dan people (personal) sebagai faktor yang mempengaruhi pembelian ulang. Sunday dan Bayode (2011) menerangkan aplikasi yang tepat dari bauran promosi atau komunikasi pemasaran dengan dimensi periklanan, promosi penjualan, pemasaran langsung dan penjualan personal, akan meningkatkan pangsa pasar dan meningkatkan pertumbuhan perusahaan menghadapi persaingan yang kuat. 
Promosi sebagai strategi meningkatkan penjualan dan membantu agar produk dikenal masyarakat. Perusahaan dapat mengkomunikasikan produk kepada konsumen melalui program-program promosi yang diantaranya periklanan, promosi penjualan, penjualan pribadi, publisitas, pemasaran langsung. Dengan promosi, konsumen akan mendapatkan informasiinformasi mengenai keunggulan produkyang dipasarkan perusahaan dan selanjutnya konsumen akan tertarik untuk mencobanya lalu memutuskan untuk membeli produk yang ditawarkan tersebut. CV. Selaksa Prada dalam merangsang keinginan konsumen untuk melakukan pembelian adalah dengan melaksanakan kegitan promosi yang di antaranya melalui pameran, membagikan brosur, beriklan pada yellow pages, instensitas kontak, melakukan tatap jual dan sebagainya.

Beberapa hasil penelitian yang pernah ada menunjukkan bahwa promosi sebagai aktivitas komunikasi pemasaran, berkontribusi terhadap pembelian ulang. Seperti yang dijelaskan oleh studi Wahyudi dan Prawatya (2012), yang menemukan bahwa variabel promosi sebagai bagian dari strategi bauran pemasaran, mampu memberikan kontribusi besar terhadap pemenuhan kepuasan konsumen. Strategi marketing mix (bauran pemasaran) suatu jasa pelayanan sangat menentukan keberhasilan perusahaan tersebut dalam menghadapi persaingan (Rahmanto et al., 2014). Demikian halnya hasil penelitian Susilowati et al. (2012) menunjukkan bahwa peningkatan strategi komunikasi pemasaran yang handal dari penyedia jasa, dapat meningkatkan keputusan konsumen dalam menggunakan suatu produk.

Hasil sebaliknya dinyatakan oleh studi Selang (2013) bahwa promosi yang merupakan kegiatan untuk mempengaruhi konsumen guna meningkatkan volume penjualan, memiliki pengaruh yang lemah terhadap loyalitas konsumen supermarket. Temuan studi Pupuani dan Sulistyawati (2013) pada pengguna pasata gigi, menunjukkan kontradiksi bahwa promosi berpengaruh tidak signifikan terhadap perilaku pembelian ulang. Hasil penelitian Fajri et al. (2013) pada nasabah bank, menunjukkan promosi sebagai usaha menginformasikan, mengingatkan, dan mempengaruhi untuk membeli produk perusahaan, tidak mempunyai pengaruh yang signifikan terhadap keputusan konsumen. Studi Malardy dan Sari (2015) menunjukkan hasil promosi sebagai bauran pemasaran jasa, tidak berdampak signifikan terhadap keputusan pembelian konsumen kafe.

Mulyono (2016) mendefinisikan corporate image sebagai kepercayaan, persepsi atau kesan keseluruhan seseorang terhadap objek atau atribut perusahaan. Citra perusahaan berdasarkan hasil studi terbukti berhubungan positif terhadap pembelian ulang konsumen (Anita, 2012; Ariyan, 2013; Mulyono, 2016; Rambe et al., 2017; Setiarini \& Hatta, 2017; Wijaya, 2013). Temuan penelitian (Sallam, 2016) menjelaskan bahwa citra perusahaan memiliki dampak positif pada kepuasan pelanggan dan kepercayaan, sehingga membentuk komunikasi word of mouth yang positif

Namun studi Qomariah (2012), Sondakh (2014), dan Pramudya et al. (2018) memberikan 
hasil sebaliknya. Qomariah (2012) menyatakan pengaruh citra perusahaan terhadap pembelian ulang tidak memiliki bukti empiris yang cukup, karena citra institusi belum mampu meningkatkan loyalitas mahasiswa. Sondakh (2014) menjelaskan citra merek berpengaruh tidak berarti terhadap kepuasan nasabah tabungan, sedangkan Pramudya dkk. (2018) mengatakan pengaruh langsung citra perusahaan terhadap intensi pembelian tidak signifikan pada perusahaan penerbangan.

Bisnis jasa perlu mengimplementasikan bauran pemasaran dengan menambahkan unsur-unsur tidak berwujud dalam strategi meningkatkan pembelian ulang. Pada aspek people kualitas penyajian layanan dapat mempengaruhi persepsi konsumen (Wilson et al., 2012). Temuan studi terdahulu menjelaskan kualitas layanan berdampak positif terhadap minat pembelian ulang (Cengiz \& Yayla, 2007; Molinari et al., 2008; Mudassar et al., 2013). Akan tetapi penelitian Qomariah (2012), menunjukkan hasil sebaliknya, kualitas layanan tidak mampu meningkatkan kepuasan dan loyalitas mahasiswa perguruan tinggi.

Research gap terkait hubungan antara promosi, citra dan kualitas layanan dengan pembelian ulang di atas, memberikan peluang penelitian lebih lanjut. Studi ini berupaya untuk mereplikasi dan mengembangkan penelitian Widjiono dan Japarianto (2014) dan Tammubua (2017), yaitu kepuasan pelanggan memediasi hubungan citra dan kualitas pelayanan terhadap loyalitas konsumen.

Penelitian ini bertujuan untuk menganalisis pengaruh promosi, citra perusahaan, dan pelayanan terhadap kepuasan pelanggan dalam meningkatkan pembelian ulang studi kasus pada CV. Selaksa Prada Semarang. Berdasarkan tujuan penelitian tersebut dikembangkan tujuh hipotesis sebagai berikut:

$\mathrm{H1}$ : Promosi berpengaruh positif pada kepuasan pelanggan.

$\mathrm{H} 2$ : Citra Perusahaan berpengaruh positif pada kepuasan pelanggan

H3 : Pelayanan berpengaruh positif pada kepuasan pelanggan

H4 : Promosi berpengaruh positif pada Pembelian ulang (rebuying) melalui kepuasan

H5 : Citra Perusahaan berpengaruh positif pada pembelian ulang melalui kepuasan

H6 : Pelayanan berpengaruh positif pada pembelian ulang melalui kepuasan pelanggan

H7 : Kepuasan pelanggan berpengaruh positif pada pembelian ulang (Re-buying).

\section{Kajian Pustaka}

\subsection{Promosi}

Kotler dan Keller (2009) mengatakan komunikasi pemasaran merupakan sarana perusahaan untuk berusaha menginformasikan, membujuk, dan mengingatkan konsumen secara langsung maupun tidak langsung tentang produk dan merek yang dijual.

Menurut Kotler dan Armstrong (2013) bauran pemasaran adalah kumpulan alat pemasaran taktis terkendali yang dipadukan perusahaan untuk menghasilkan respons yang diinginkannya di pasar sasaran. Menurut Lovelock et al. (2010) pada bauran pemasaran jasa selain product, price, place, dan promotion, perlu diperluas dengan menambahkan people 
(manusia), process (proses), dan physical evidence (lingkungan fisik) sehingga keseluruhan elemen bauran pemasaran menjadi 7P.

Promosi adalah menyampaikan pesan yang jelas, konsisten, dan menarik tentang organisasai dan merek. Lima alat promosi utama adalah periklanan (advertising), promosi penjualan (sales promotion), penjualan pribadi (personal selling), hubungan masyarakat (public relation), dan pemasaran langsung (direct marketing) (Kotler \& Armstrong, 2013).

\subsection{Citra Perusahaan}

Kotler (2000) mengatakan citra perusahaan merupakan cara perusahaan menampilkan identitas dirinya pada masyarakat yang berupa logo perusahaan, visi dan misi institusi, atau penampilan fisik institusi yang membedakannya dengan institusi pesaing.

\subsection{Pelayanan}

Payne (2006) mendefinisikan kualitas layanan sebagai kemampuan sebuah perusahaan dalam memberikan layanan untuk member harapan pelanggan. Definisi tersebut menekankan pada pemenuhan harapan pelanggan tetapi belum mencerminkan sebuah keunggulan dari pelanggan yang diberikan kepada pelanggan. Pelayanan dapat dikatakan berkualitas apabila kinerja pelayanan dapat memenuhi harapan pelanggan.

\subsection{Kepuasan Pelanggan}

Kotler dan Keller (2009) mendefinisikan kepuasan pelanggan sebagai perasaaan seseorang dari kesenangan atau kekecewaan yang dihasilkan dari membandingkan produk yang dirasakan kinerja (atau hasil) dalam kaintannya dengan harapannya.

\subsection{Pembelian Ulang}

Kotler (1997) menyatakan pembelian ulang merupakan salah satu perilaku setelah pembelian yang sebelumnya didasari dengan kepuasan. Jika pelanggan merasa puas untuk selanjutnya dia akan memperlihatkan peluang membeli yang lebih tinggi dalam kesempatan beikutnya

\section{Metode Penelitian}

\subsection{Populasi dan Sampel}

Populasi dalam penelitian ini adalah pemakai jasa (user) dari CV. Selaksa Prada yang menurut data dua tahun terakhir sebanyak 53 user. Teknik pengambilan sampel yang digunakan dalam penelitian ini yaitu sensus, yaitu mengambil secara seluruh jumlah sampel yang merupakan jumlah populasi (Sugiyono, 2010). 


\subsection{Teknik Pengumpulan Data}

Dalam penelitian ini, pengumpulan data dilakukan dengan menggunakan kuesioner yaitu suatu metode pengumpulan data dengan memberikan atau menyebarkan daftar pertanyaan kepada responden.

\subsection{Definisi Konsep}

Konsep-konsep yang terdapat dalam penelitian ini adalah citra perusahaan, promosi, pelayanan, kepuasan pelangan dan re-buying. Hasil impresi (kesan) yang dibuat oleh keseluruhan entitas (seperti iklan) dibenak individual pelanggan. Bauran komunikasi pemasaran atau bauran promosi (promotion mix) dalam penelitian ini diukur dengan lima dimensi yaitu: periklanan (advertising), promosi penjualan (sales promotion), hubungan masyarakat dan publisitas (publicity), penjualan tatap muka (personal selling), dan pemasaran lewat internet (internet marketing).

Citra perusahaan merupakan keseluruhan kesan yang terbentuk dibenak masyarakat tentang perusahaan. Citra perusahaan diukur dengan indikator: atribut produk, orang dan relationship terkait orientasi pada pelanggan, nilai dan program terkait kepedulian lingkungan dan tanggungjawab sosial, dan kredibilitas perusahaan (corporate credibility).

Pelayanan adalah hasil dari sebuah proses dimana harapan pelanggan untuk layanan ini dibandingkan dengan persepse merreka terhadap pelayanan. Pelayanan diukur dengan dimensi: Responsiveness (daya tanggap), reliability (kehandalan), assurance (jaminan), dan emphaty (empati).

Kepuasan pelanggan adalah keseluruhan sikap yang ditunjukkan pelanggan atas pelayanan barang atau jasa setelah pelanggan tersebut memperoleh dan menggunakannya. Kepuasan pelanggan diukur dengan dimensi: kualitas produk, harga, kualitas jasa, emotional factor, biaya atau kemudahan mendapatkan produk atau jasa.

Pembelian ulang adalah keinginan pembeli untuk melakukan kunjungan ulang di masa yang akan datang. Pembelian ulang diukur dengan dimensi: keinginan untuk membeli, merekomendasikan yang meliputi kebutuhan, ketertarikan, dan keinginan membeli kembali.

\subsection{Teknik Analisis Data}

Analisis regresi, digunakan untuk melihat bagaimana pengaruh dari variabel bebas terhadap variabel tidak bebas. Dalam penelitian ini analisis regresi dilakukan dengan dua cara yang pertama merupakan regresi langsung (untuk mengetahui pengaruh promosi, citra perusahaan dan pelayanan terhadap kepuasan pelanggan) dan yang kedua adalah analisis regresi dengan variabel mediasi yang dilakukan dengan tujuan untuk mengetahui pengaruh promosi, citra perusahaan dan pelayanan terhadap kepuasan pelanggan serta implikasinya pada pembelian ulang. 
Koefisien determinasi (Adjusted $R$ Square) digunakan untuk mengetahui seberapa besar prosentase yang mampu dijelaskan oleh variabel promosi, citra perusahaan dan pelayanan terhadap kepuasan pelanggan serta implikasinya pada pembelian ulang. Uji t digunakan untuk melihat seberapa jauh pengaruh satu variabel independen secara individual dalam menerangkan variasi variabel dependen. Pengujian melalui uji t dilakukan dengan membandingkan $\mathrm{t}$ hitung dengan $\mathrm{t}$ tabel pada alpha $=5 \%(0,05)$. Uji $\mathrm{F}$ menunjukkan seberapa jauh pengaruh semua variabel independen secara bersama-sama dalam menerangkan variabel dependen. Pengujian melalui uji $\mathrm{F}$ dilakukan dengan membandingkan $\mathrm{F}$ hitung dengan $\mathrm{F}$ tabel pada alpha $=5 \%(0,05)$ (Ghozali, 2011).

Untuk mengetahui efek mediasi dari suatu variabel mediasi digunakan analisis jalur atau path analysis. Analisis jalur adalah penggunaan analisis regresi untuk menaksir hubungan kausalitas antar variabel yang telah ditetapkan sebelumnya berdasarkan teori. Apa yang dapat dilakukan oleh analisis jalur adalah menentukan pola pengaruh antara 3 atau lebih variabel dan tidak dapat digunakan untuk menkonfirmasi atau menolak hipotesis kausalitas imajiner (Ghozali, 2011). Pengujian mediasi dengan dilakukan dengan Sobel Tes. Proses perhitungan pengujian mediasi pada penelitian ini tidak dilakukan secara manual, namun dilakukan dengan calculation for Sobel test pada website http://quantpsy.org/sobel/sobel.htm (Ngatno, 2015).

\section{Temuan dan Diskusi}

Temuan penelitian terkait dengan uji validitas, uji reliabilitas, analisis jalur, uji peran mediasi dengan Sobel Test, dan pengaruh variabel dominan dapat dijelaskan sebagai berikut:

\section{Tabel 2.}

Hasil Uji Validitas

\begin{tabular}{|l|c|c|}
\hline \multicolumn{1}{|c|}{ Variabel } & Nilai $\boldsymbol{r}$ hitung & Kriteria \\
\hline Promosi & $0,793 \mathrm{sd} 0,930$ & Valid \\
\hline Citra perusahaan & $0,790 \mathrm{sd} 0,906$ & Valid \\
\hline Pelayanan & $0,851 \mathrm{sd} 0,911$ & Valid \\
\hline Kepuasan pelanggan & $0,762 \mathrm{sd} 0,891$ & Valid \\
\hline Pembelian Ulang & $0,803 \mathrm{sd} \mathrm{0,896}$ & Valid \\
\hline
\end{tabular}

Sumber: olah data peneliti

Berdasarkan Tabel 2 pengujian validitas pada variabel bebas $(x)$ dan variabel terikat (y), diketahui angka $r$ hitung $>$ angka $r$ tabel $(0,2706)$, maka semua instrumen (item pertanyaan/ indikator) dinyatakan valid, sehingga layak untuk digunakan sebagai instrumen penelitian. 
Tabel 3.

Hasil Uji Reliabilitas

\begin{tabular}{|c|c|c|}
\hline Variabel & Alpha Cronbach & Kriteria \\
\hline Promosi & 0,970 & Reliabel \\
\hline Citra perusahaan & 0,958 & Reliabel \\
\hline Pelayanan & 0,968 & Reliabel \\
\hline Kepuasan pelanggan & 0,965 & Reliabel \\
\hline Pembelian Ulang & 0,961 & Reliabel \\
\hline
\end{tabular}

Pada pengujian reliabilitas pada Tabel 3 diketahui Alpha Cronbach variabel promosi, citra perusahaan, pelayanan, kepuasan pelanggan, dan pembelian ulang $>0,6$ sehingga dikatakan reliabel.

Tabel 4.

Hasil Uji T, Uji F dan Koefisien Determinasi

\begin{tabular}{|c|c|c|}
\hline Variabel Independen & B & Sig. \\
\hline Promosi & 0,800 & 0,000 \\
\hline Citra & 0,783 & 0,000 \\
\hline Pelayanan & 0,777 & 0,000 \\
\hline \multicolumn{2}{|c|}{ Variabel dependen: Kepuasan Pelanggan } \\
\hline Konstanta =0,319; Adjusted r square = 0,685; Sig. F=0,000. & 0,000 \\
\hline Promosi & 0,887 & 0,000 \\
\hline Citra & 0,882 & 0,000 \\
\hline Pelayanan & 0,828 & 0,000 \\
\hline Kepuasan Pelanggan & 0,972 & Variabel dependen: Pembelian Ulang \\
\hline \multicolumn{2}{|c|}{ Konstanta = -0,163; Adjusted r square = 0,885; Sig. F = 0,000. } \\
\hline
\end{tabular}

Sumber: olah data peneliti

Berdasarkan hasil pengolahan data pada Tabel 4 diperoleh persamaan regresi yaitu :

$Y_{1}=0.319+0,280 x_{1}+0,245 x_{2}+0,395 x_{3} \ldots .(1)$

$Y_{2}=-0.163+0,224 x_{1}+0,265 x_{2}+0,184 x_{3}+0,373 Y_{1}$

Angka koefisien determinasi (adjusted rsquare) pertama sebesar 0,685. Hal ini berarti bahwa variabel promosi $\left(\mathrm{x}_{1}\right)$, citra $\left(\mathrm{x}_{2}\right)$ dan pelayanan $\left(\mathrm{x}_{3}\right)$ terhadap kepuasan pelanggan $\left(\mathrm{y}_{1}\right)$ memiliki konstribusi sebesar $68,5 \%$. Faktor-faktor lain yang berpengaruh terhadap kepuasan pelanggan memiliki kontribusinya sebesar $(100 \%-68,5 \%)=31,5 \%$.

Angka koefisien determinasi (adjusted r square) kedua sebesar 0,885. Hal ini berarti bahwa variabel promosi $\left(x_{1}\right)$, citra $\left(x_{2}\right)$, pelayanan $\left(x_{3}\right)$ dan kepuasan pelanggan $\left(y_{1}\right)$ terhadap 
pembelian ulang $\left(\mathrm{y}_{2}\right)$ memiliki konstribusi sebesar $88,5 \%$, sedangkan faktor-faktor lain yang berpengaruh terhadap pembelian ulang memiliki kontribusinya sebesar $(100 \%-88,5 \%)=$ $11,5 \%$.

Hipotesis pertama menyatakan bahwa promosi berpengaruh positif dan signifikan terhadap kepuasan pelanggan. Berdasarkan hasil pengolahan data pada Tabel 3 diperoleh angka probabilitas sebesar $0,000<$ taraf signifikansi $\alpha=5 \%(0,05)$ antara promosi $\left(x_{1}\right)$ terhadap kepuasan pelanggan $\left(_{1}\right)$; berarti secara parsial (individu) terdapat pengaruh yang positif dan signifikan antara promosi $\left(\mathrm{x}_{1}\right)$ terhadap kepuasan pelanggan $\left(\mathrm{y}_{1}\right)$ dengan koefisien regresi positif sebesar 0,800. Berdasarkan data tersebut maka hipotesis pertama yang menyatakan bahwa promosi berpengaruh positif dan signifikan terhadap kepuasan pelanggan, dapat diterima.

Hipotesis kedua menyatakan bahwa citra berpengaruh positif dan signifikan terhadap kepuasan pelanggan. Dari hasil pengolahan data pada Tabel 3 diperoleh angka probabilitas sebesar $0,000<$ taraf signifikansi $\alpha=5 \%(0,05)$ antara citra $\left(x_{2}\right)$ terhadap kepuasan pelanggan $\left(\mathrm{y}_{1}\right)$; berarti secara parsial (individu) terdapat pengaruh yang positif dan signifikan antara citra $\left(x_{2}\right)$ terhadap kepuasan pelanggan $\left(\mathrm{y}_{1}\right)$ dengan koefisien regresi positif sebesar 0,783 (b2). Dengan demikian hipotesis kedua yang menyatakan bahwa citra berpengaruh positif dan signifikan terhadap kepuasan pelanggan, dapat diterima.

Hipotesis ketiga menyatakan bahwa pelayanan berpengaruh positif dan signifikan terhadap kepuasan pelanggan. Dari hasil pengolahan data pada Tabel 3 diperoleh angka probabilitas sebesar $0,000<$ taraf signifikansi $\alpha=5 \%(0,05)$ antara pelayanan $\left(x_{3}\right)$ terhadap kepuasan pelanggan $\left(\mathrm{y}_{1}\right)$; berarti secara parsial (individu) terdapat pengaruh yang positif dan signifikan antara pelayanan $\left(\mathrm{x}_{3}\right)$ terhadap kepuasan pelanggan $\left(\mathrm{y}_{1}\right)$ dengan koefisien regresi positif sebesar 0,777 . Dengan demikian hipotesis ketiga yang menyatakan bahwa pelayanan berpengaruh positif dan signifikan terhadap kepuasan pelanggan, dapat diterima.

Hipotesis keempat menyatakan bahwa promosi berpengaruh positif dan signifikan terhadap pembelian ulang. Dari hasil pengolahan data pada Tabel 3 diperoleh angka probabilitas sebesar $0,000<$ taraf signifikansi $\alpha=5 \%(0,05)$ antara promosi $\left(x_{1}\right)$ terhadap kepuasan pelanggan $\left(\mathrm{y}_{1}\right)$; berarti secara parsial (individu) terdapat pengaruh yang positif dan signifikan antara promosi $\left(x_{1}\right)$ terhadap pembelian ulang $\left(\mathrm{y}_{2}\right)$ dengan koefisien regresi positif sebesar 0,887 . Dengan demikian hipotesis keempat yang menyatakan bahwa promosi berpengaruh positif dan signifikan terhadap pembelian ulang, diterima.

Hipotesis kelima menyatakan bahwa citra berpengaruh positif dan signifikan terhadap pembelian ulang. Dari hasil pengolahan data diperoleh angka probabilitas sebesar $0,000<$ taraf signifikansi $\alpha=5 \%(0,05)$ antara citra $\left(x_{2}\right)$ terhadap pembelian ulang $\left(y_{2}\right)$; berarti secara parsial (individu) terdapat pengaruh yang positif dan signifikan antara citra $\left(\mathrm{x}_{2}\right)$ terhadap pembelian ulang $\left(y_{2}\right)$ dengan koefisien regresi sebesar 0,882. Dengan demikian hipotesis 
keenam yang menyatakan bahwa citra berpengaruh positif dan signifikan terhadap pembelian ulang, diterima.

Hipotesis keenam menyatakan bahwa pelayanan berpengaruh positif dan signifikan terhadap pembelian ulang. Dari hasil pengolahan data diperoleh angka probabilitas sebesar $0,000<$ taraf signifikansi $\alpha=5 \%(0,05)$ antara pelayanan $\left(x_{3}\right)$ terhadap pembelian ulang $\left(\mathrm{y}_{2}\right)$; berarti secara parsial (individu) terdapat pengaruh yang positif dan signifikan antara pelayanan $\left(x_{3}\right)$ terhadap pembelian ulang $\left(y_{2}\right)$ dengan koefisien regesi sebesar 0,828 . Dengan demikian hipotesis keenam yang menyatakan bahwa pelayanan berpengaruh positif dan signifikan terhadap pembelian ulang, diterima.

Hipotesis ketujuh menyatakan bahwa kepuasan pelanggan berpengaruh positif dan signifikan terhadap pembelian ulang. Dari hasil pengolahan data diperoleh angka probabilitas sebesar $0,000<$ taraf signifikansi $\alpha=5 \%(0,05)$ antara kepuasan pelanggan $\left(\mathrm{y}_{1}\right)$ terhadap pembelian ulang $\left(\mathrm{y}_{2}\right)$; berarti secara parsial (individu) terdapat pengaruh yang positif dan signifikan antara kepuasan pelanggan $\left(\mathrm{y}_{1}\right)$ terhadap pembelian ulang $\left(\mathrm{y}_{2}\right)$ dengan koefisien regresi positif sebesar 0,972 . Dengan demikian hipotesis keenam yang menyatakan bahwa kepuasan pelanggan berpengaruh positif dan signifikan terhadap pembelian ulang, diterima.

Tabel 5.

Hasil Uji Mediasi dengan Sobel Test

\begin{tabular}{|c|c|}
\hline \multicolumn{1}{|c|}{ Efek Mediasi } & T-Hitung \\
\hline \multicolumn{1}{|c|}{ Promosi $\rightarrow$ Kepuasan Pelanggan } & 2,70 \\
\hline Citra Perusahaan $\rightarrow$ Kelian Ulang & 8,65 \\
\hline Pepuasan Pelanggan & 9,36 \\
\hline Pembelian Ulang & \\
\hline
\end{tabular}

Sumber: olah data peneliti

Berdasarkan perhitungan di Tabel 5 diperoleh semua nilai t-hitung sobel test lebih besar dibandingkan dengan $t$ tabel1,68. Dengan demikian dapat disimpulkan bahwa variabel kepuasan pelanggan secara signifikan sebagai variabel mediasi pengaruh promosi, citra perusahan dan pelayanan terhadap pembelian ulang. Berdasarkan hasil sebelumnya diketahui promosi, citra perusahan dan pelayanan secara signifikan berpengaruh langsung terhadap pembelian ulang, sehingga peran kepuasan pelanggan adalah mediasi partial (partial mediation). 
Tabel 6.

Hasil Perhitungan Pengaruh Total

\begin{tabular}{|c|c|c|c|c|}
\hline $\begin{array}{c}\text { Variabel In- } \\
\text { dependen }\end{array}$ & $\begin{array}{c}\text { Variabel } \\
\text { Dependen }\end{array}$ & $\begin{array}{c}\text { Pengaruh } \\
\text { Langsung }\end{array}$ & $\begin{array}{c}\text { Pengaruh Tidak } \\
\text { Langsung }\end{array}$ & Pengaruh Total \\
\hline Promosi & $\begin{array}{c}\text { Pembelian } \\
\text { Ulang }\end{array}$ & 0,887 & $0,800 \times 0,972=0.778$ & $0,887+0,778=1,665$ \\
\hline $\begin{array}{c}\text { Citra } \\
\text { Perusahaan }\end{array}$ & 0,882 & $0,783 \times 0,972=0,761$ & $0,882+0,761=1,643$ \\
\hline Pelayanan & & 0,828 & $0,777 \times 0,972=0,755$ & $0,828+0,775=1,583$ \\
\hline
\end{tabular}

Sumber: olah data peneliti

Berdasarkan Tabel 6 dapat dijelaskan variabel yang memiliki pengaruh paling dominan terhadap pembelian ulang adalah promosi dengan koefisien jalur sebesar 1,885 , diikuti citra perusahaan dengan koefisien jalur 1,643, dan pelayanan dengan koefisien jalur sebesar 1,583.

Hasil perhitungan menunjukkan adanya pengaruh positif promosi terhadap kepuasan pelanggan, ini berarti bahwa semakin tinggi promosi yang dilakukan oleh perusahaan, maka semakin tinggi pula kepuasan yang dirasakan oleh pelanggan. Dengan kata lain usaha-suaha persuasi langsung melalui periklanan, personal selling, publisitas, promosi penjualan, dan internet marketing akan membawa dampak positif bagi kepuasan pelanggan.

Penelitian ini mendukung temuan Wahyudi dan Prawatya (2013) yang menemukan bahwa variabel promosi sebagai bagian dari strategi bauran pemasaran, mampu memberikan kontribusi besar terhadap pemenuhan kepuasan konsumen. Promosi merupakan aspek vital dalam menciptakan kepuasan konsumen, sehingga sangat penting bagi perusahaan yag tetap ingin bertahan dalam menciptakan keunggulan kompetitif yang berkesinambungan. Strategi marketing mix (bauran pemsaran) suatu jasa pelayanan sangat menentukan keberhasilan perusahaan tersebut dalam menghadapi persaingan (Wahyudi dan Prawatya, 2013).

Hasil penelitian yang menunjukkan pengaruh positif promosi terhadap kepuasan pelanggan mendukung studi Rahmanto et al. (2014), bahwa promosi sebagai dimensi marketing mix memiliki hubungan positif terhadap kepuasan pelanggan. Penggunaan media sosial internet dipercaya sebagai sarana promosi yang komunikatif, sehingga berdampak pada dimensi kepuasan pelanggan yang meliputi create value (nilai yang diciptakan), communication value (nilai komunikasi), dan delivery value (nilai yang ditawarkan).

Temuan empiris dari studi ini menjelaskan adanya pengaruh positif citra terhadap kepuasan pelanggan, artinya semakin baik citra perusahaan di mata pelanggan akan mendorong kepuasan konsumen. Hal ini sejalan dengan riset Sallam (2016) yang berhasil menguji pengaruh positif citra perusahaan terhadap kepuasan pelanggan. Penelitian pada perilaku konsumen pelayanan berbagai jenis mobil di arab saudi menunjukkan bahwa citra perusahaan berdampak 
terhadap kepercayaan serta kepuasan pelanggan, dan pada akhirnya meningkatkan word of mouth. Hasil studi memberikan bukti empiris bahwa terdapat hubungan yang kuat antara citra perusahaan dengan kepuasan pelanggan.

Hasil studi ini menjelaskan adanya pengaruh positif pelayanan terhadap kepuasan pelanggan, artinya semakin baik kualitas pelayanan diberikan kepada konsumen maka semakin tinggi perasaan puas yang didapatkannya. Hal ini mendukung teori kepuasan pelanggan Parasuraman et al. (1985) yang menjelaskan pelanggan mengevaluasi kinerja perusahaan secara keseluruhan baik dari segi kualitas produk dan kualitas pelayanan.

Temuan empiris studi ini linier dengan hasil riset Mudassar et al. (2012) tentang pengaruh kualitas pelayanan pada kepuasan pelanggan. Mengambil studi pada pelanggan restoran cepat saji, hasil penelitian menunjukkan adanya hubungan positif langsung kualitas pelayanan pada kepuasan pelanggan. Model SERVQUAL yang terdiri lima dimensi terbukti secara empiris mendorong diperolehnya harapan konsumen sehingga menjadikannya loyal.

Hasil pengujian statistik diketahui bahwa semakin tinggi upaya-upaya komunikasi pemasaran maka akan meningkatkan pembelian ulang oleh konsumen. Hal ini selaras dengan hasil studi Cengiz dan Yahya (2007) bahwa promosi sebagai komponen bauran pemasaran berpengaruh pada komunikasi word of mouth. Marketing mix terbukti membawa peningkatan keunggulan kompetitif dalam pemasaran, karena dalam jangka panjang mampu menumbuhkan loyalitas konsumen.

Hasil studi menunjukkan adanya pengaruh positif citra terhadap pembelian ulang. Temuan ini mendukung riset sebelumnya oleh Anita (2012) dan Wijaya (2013). Citra perusahaan yang baik terbukti secara empiris meningkatkan kemungkinan konsumen menggunakan kembali produk perusahaan yang ditawarkan. Semakin positif citra dalam benak konsumen, maka semakin besar niat pembelian ulang konsumen tersebut. Namun hasil riset ini tidak sejalan dengan studi sebelumya (Widjiono et al., 2015) bahwa tidak terdapat pengaruh yang signifikan self image (citra) terhadap customer satisfaction (kepuasan pelanggan).

Temuan studi bahwa kualitas layanan berdampak positif terhadap minat pembelian ulang, sejalan dengan riset Molinari et al. (2008). Kualitas layanan terbukti secara empiris berhubungan positif signifikan terhadap komunikasi dari mulut ke mulut. Parasuraman et al. (1985) menyatakan kualitas layanan memegang peranan sentral dalam hubungan jangka panjang dengan pelanggan. Evaluasi atas pelayanan yang diberikan apabila sama bahkan melebihi harapan pelanggan, akan menimbulkan keuntungan diferensial dan membuat hubungan yang baik, yang mempengaruhi kepuasan dan loyalitas pelanggan.

Adanya pengaruh positif kepuasan pelanggan terhadap pembelian ulang sebagai hasil studi ini, sesuai dengan hasil penelitian Molinari et al. (2008). Kepuasan hasil studinya terbukti empiris berhubungan positif signifikan dengan intensi (niat) untuk pembelian ulang, sebagai intensi perilaku positif konsumen pelanggan perusahaan ekspedisi, jalur kapal uap, maskapai 
penerbangan, pengemas, perusahaan kereta api dan truk di amerika serikat. Demikian halnya hasil penelitian ini sesuai dengan temuan studi sebelumya Widjiono et al. 2015) bahwa customer satisfaction berpengaruh positif signifikan terhadap repurchase intention.

Hasil temuan efek mediasi pertama dari kepuasan pelanggan dalam memediasi pengaruh promosi terhadap pembelian ulang diperoleh bahwa kepuasan pelanggan mampu memediasi pengaruh promosi terhadap pembelian ulang. Hal ini menunjukkan bahwa promosi yang sering dan kepuasan pelanggan yang tinggi dari pelanggan mampu meningkatkan pembelian ulang bagi klien. Temuan efek mediasi kepuasan pelanggan pada hubungan promosi dengan pembelian ulang, adalah selaras dengan studi Tammubua (2017) bahwa promosi merupakan upaya pemasaran yang digunakan perusahaan, akan menimbulkan kepuasan konsumen sehingga diharapkan menciptakan loyalitas dalam bentuk pembelian ulang. Namun hasil studi ini tidak sejalan dengan hasil studi Widyaningtyas et al. (2016). Promosi sebagai bagian dari marketing mix tidak ada hubungannya dengan kepuasan pelangan dan loyalitas konsumen.

Hasil temuan efek mediasi kedua dari kepuasan pelanggan dalam memediasi pengaruh citra terhadap pembelian ulang diperoleh bahwa kepuasan pelanggan mampu memediasi pengaruh citra terhadap pembelian ulang. Hal ini menunjukkan bahwa citra yang baik dan kepuasan pelanggan yang tinggi dari pelanggan mampu meningkatkan pembelian ulang bagi klien. Hasil ini memperkuat studi Tammubua (2017) bahwa customer satisfaction memediasi penuh pengaruh image terhadap customer loyalty. Namun hasil riset ini tidak sejalan dengan studi sebelumya (Widjiono et al., 2015) bahwa customer satisfaction bukan variabel intervening, karena secara empiris tidak terdapat pengaruh yang signifikan self image (citra) terhadap customer satisfaction (kepuasan pelanggan).

Hasil temuan efek mediasi ketiga dari kepuasan pelanggan dalam memediasi pengaruh pelayanan terhadap pembelian ulang diperoleh bahwa kepuasan pelanggan mampu memediasi pengaruh pelayanan terhadap pembelian ulang. Hal ini menunjukkan bahwa pelayanan yang baik dan kepuasan pelanggan yang tinggi dari pelanggan mampu meningkatkan pembelian ulang bagi klien. Temuan ini sesuai dengan hasil studi Tammubua (2017) bahwa customer satisfaction memediasi penuh pengaruh retail service quality terhadap customer loyalty. Namun hasil riset ini berlawanan dengan studi sebelumya Widjiono et al. (2015) bahwa customer satisfaction bukan variabel intervening, karena secara empiris customer perceived service quality tidak berhubungan signifikan terhadap customer satisfaction (kepuasan pelanggan).

\section{Simpulan dan Saran}

Berdasarkan hasil penelitian, maka dapat diambil beberapa kesimpulan sebagai berikut: (1) secara parsial terdapat pengaruh yang positif dan signifikan antara promosi, citra perusahaan, dan pelayanan terhadap kepuasan pelanggan; (2) secara parsial terdapat pengaruh yang positif dan signifikan antara promosi, citra perusahaan, pelayanan dan kepuasan pelanggan 
terhadap pembelian ulang; (3) kepuasan pelanggan terbukti memediasi secara partial (partial mediation) pengaruh promosi, citra perusahaan, dan pelayanan terhadap pembelian ulang; (4) variabel yang memiliki pengaruh paling dominan terhadap pembelian ulang adalah promosi, diikuti citra perusahaan, dan pelayanan.

Penelitian ini hanya menggunakan variabel promotion dan people sebagai strategi marketing mix. Oleh karenanya penelitian mendatang sebaiknya memperluas cakupan marketing mix (bauran pemasaran) dengan menambahkan variabel product, price, place, process, dan physical evidence sehingga diharapkan melengkapi temuan faktor-faktor yang menjelaskan kepuasan pelanggan dan pembelian ulang.

\section{Daftar Pustaka}

Anita. 2012. Pengaruh Store Image, Product Signatureness, dan Quality Variation Terhadap Repurchase Intention Produk Private Label Melalui Quality Perception di Carrefour Surabaya. Jurnal IImiah Mahasiswa Manajemen, 1(2), 19-25.

Ariyan, H. 2013. Pengaruh brand awareness dan kepercayaan konsumen atas merek terhadap keputusan pembelian ulang minuman Aqua di Kota Padang. Jurnal Manajemen, 2(01), $1-11$.

Cengiz, E., \& Yayla, H. E. 2007. The effect of marketing mix on positive word of mouth communication: Evidence from accounting offices in Turkey. Innovative Marketing, 3(4), 73-86.

Fajri, D. A., Arifin, Z., \& Wilopo. 2013. Pengaruh Bauran Pemasaran Jasa terhadap Keputusan Menabung (survei pada nasabah bank muamalat cabang malang). Jurnal Administrasi Bisnis, 6(2), 1-10.

Ghozali, I. 2011. Aplikasi Analisis Multivariate dengan Program IBM SPSS 19 (Edisi 5 ed.). Semarang: Badan Penerbit Universitas Diponegoro.

Kotler, P. 1997. Manajemen Pemasaran Analysis Perencanaan dan Pengendalian. Jakarta: Erlangga.

Kotler, P. 2000. Riset Pemasaran dan Perilaku Konsumen: Jakarta: PT Gramedia Pustaka Utama.

Kotler, P., \& Armstrong, G. 2013. Dasar-Dasar Pemasaran: Principles of Marketing. Jakarta: Intermedia.

Kotler, P., \& Keller, K. L. 2009. Manajemen Pemasaran, Edisi 13 Jilid 1. Jakarta: Erlangga.

Lovelock, C., Wirtz, J., \& Mussry, J. 2010. Pemasaran Jasa. Jakarta: Erlangga.

Malardy, M. A., \& Sari, D. 2015. Pengaruh Bauran Pemasaran Jasa Terhadap Keputusan Pembelian Konsumen Di Siete Cafe \& Garden Bandung. eProceedings of Management, 2(2), 1941-1950. 
Molinari, L. K., Abratt, R., \& Dion, P. 2008. Satisfaction, quality and value and effects on repurchase and positive word-of-mouth behavioral intentions in a B2B services context. Journal of Services Marketing, 22(5), 363-373.

Mudassar, K., Talib, S., Cheema, S., \& Raza, M. S. 2013. The impact of service quality on customer satisfaction and the moderating role of word-of-mouth. African Journal of Business Management, 7(18), 1751-1756.

Mulyono, H. 2016. Pengaruh Orientasi Pasar dan Citra terhadap Kepuasan Mahasiswa dan Implikasinya terhadap Loyalitas Mahasiswa. Jurnal Aplikasi Manajemen, 14(3), 515527.

Ngatno. 2015. Analisis Data Variabel Mediasi dan Modeasi Dalam Riset Bisnis Dengan Program SPSS. Yogyakarta: Popub Design.

Parasuraman, A., Zeithaml, V. A., \& Berry, L. L. 1985. Servqual: A multiple-item scale for measuring consumer perc. Journal of retailing, 64(1), 12-40.

Payne, A. 2006. The Essence Of Service Marketing Pemasaran Jasa Edisi II (Terjemahan Fandy Tjiptono). Yogyakarta: Penerbit Andi. .

Pramudya, A. K., Sudiro, A., \& Sunaryo, S. 2018. The Role of Customer Trust in Mediating Influence of Brand Image and Brand Awareness of The Purchase Intention in Airline Tickets Online. Jurnal Aplikasi Manajemen, 16(2), 224-233.

Pupuani, N. W., \& Sulistyawati, E. 2013. Pengaruh Bauran Pemasaran Terhadap Kepuasan Konsumen Dan Perilaku Pembelian Ulang. E-Jurnal Manajemen Universitas Udayana, 2(6), 683-702.

Qomariah, N. 2012. Pengaruh Kualitas Layanan dan Citra Institusi Terhadap Kepuasan dan Loyalitas Pelanggan (Studi pada Universitas Muhammadiyah di Jawa Timur). Jurnal Aplikasi Manajemen, 10(1), 177-187.

Rahmanto, V., Sugiono, S., \& Rahman, A. 2014. Analisis Pengaruh Lingkungan Pemasaran Dan Marketing Mix Terhadap Kepuasan Pelanggan Menggunakan Structural Equation Modelling (Studi Kasus: CV. Dea Cake \& Bakery). Jurnal Rekayasa dan Manajemen Sistem Industri, 2(1), 57-66.

Rambe, N., Maksum, C., \& Yasin, M. 2017. Pengaruh Pelayanan, Citra Merek dan Harga Terhadap Pembelian Ulang Melalui Kepuasan Pelanggan dan Word of Mouth. EKOBISMANJURNAL EKONOMI BISNIS MANAJEMEN, 1(3), 1-21.

Sallam, M. A. 2016. An Investigation of Corporate Image Effect on WOM: The Role of Customer Satisfaction and Trust. International Journal of Business Administration, 7(3), 27.

Selang, C. A. 2013. Bauran pemasaran (marketing mix) pengaruhnya terhadap loyalitas konsumen pada fresh mart bahu mall manado. Jurnal EMBA: Jurnal Riset Ekonomi, Manajemen, Bisnis dan Akuntansi, 1(3), 71-80. 
Setiarini, \& Hatta, I. H. 2017. Membangun Citra Yang Mendukung Loyalitas. EKOBISMANJURNAL EKONOMI BISNIS MANAJEMEN, 2(2), 205-219.

Sondakh, C. 2014. Kualitas Layanan, Citra Merek Dan Pengaruhnya Terhadap Kepuasan Nasabah Dan Loyalitas Nasabah Tabungan (Studi Pada Nasabah Taplus BNI Cabang Manado). Jurnal Riset Bisnis dan Manajemen, 3(1), 19-32.

Sugiyono, D. 2010. Metode penelitian kuantitatif kualitatif dan R\&D. Penerbit Alfabeta.

Susilowati, C., Thoyib, A., \& Permanasari, K. I. 2012. Pengaruh Komunikasi Pemasaran terhadap Keputusan Konsumen dalam Menggunakan Kartu Seluler IM3 melalui Motivasi Konsumen (Studi pada Pengguna IM3 di Malang). Jurnal Aplikasi Manajemen, 10(1), 97-106.

Tammubua, M. H. 2017. Analisa Pengaruh Self Image Congruity, Retail Service Quality, Dan Customer Perceived Service Quality Terhadap Customer Loyalty Yang Dimediasi Customer Satisfaction Urban Surf/Distro Di Jayapura.Jurnal Organisasi Dan Manajemen, 13(2), 166-179.

Wahyudi, T., \& Prawatya, Y. E. 2012. Analisis Pengaruh Marketing Mix Terhadap Kepuasan Konsumen Sepeda Motor. Jurnal ELKHA, 4(2), 34-38.

Widjiono, L. M., \& Japarianto, E. 2014. Analisa Pengaruh Self Image Congruity, Retail Service Quality, Dan Customer Perceived Service Quality Terhadap Repurchase Intention Dengan Customer Satisfaction Sebagai Variabel Intervening Di Broadway Barbershop Surabaya. Jurnal Manajemen Pemasaran, 9(1), 35-42.

Wijaya, C. H. 2013. Pengaruh Store Image, Store Atmospherics, dan Store Theatrics Terhadap Purchase Intention Pada The Body Shop Galaxy Mall Surabaya. Kajian IImiah Mahasiswa Manajemen, 2(4), 1-8.

Wilson, A., Zeithaml, V. A., Bitner, M. J., \& Gremler, D. D. 2012. Services marketing: Integrating customer focus across the firm: McGraw Hill. 